\title{
Fermented Herbal Formulas KIOM-MA128 Ameliorate IL-6-Induced Intestinal Barrier Dysfunction in Colon Cancer Cell Line
}

\author{
Kwang Il Park, Dong Gun Kim, Bo Hyoung Lee, and Jin Yeul Ma \\ Korean Medicine (KM) Application Center, Korea Institute of Oriental Medicine (KIOM), 70 Cheomdan-ro, Dong-gu, \\ Daegu 41062, Republic of Korea \\ Correspondence should be addressed to Jin Yeul Ma; jyma@kiom.re.kr
}

Received 18 August 2016; Revised 24 October 2016; Accepted 26 October 2016

Academic Editor: Tânia Silvia Fröde

Copyright (C) 2016 Kwang Il Park et al. This is an open access article distributed under the Creative Commons Attribution License, which permits unrestricted use, distribution, and reproduction in any medium, provided the original work is properly cited.

\begin{abstract}
Inflammatory bowel disease (IBD) comprises Crohn's disease (CD) and ulcerative colitis (UC). IBD increases the risk of colorectal cancer (CRC), depending on the extent and duration of intestinal inflammation. Increased IL-6 expression has been reported in IBD patients, which may be associated with intestinal barrier function through discontinuous tight junction (TJ). KIOM-MA is a specific agent for allergic diseases and cancer, and it is composed of several plants; these herbs have been used in traditional oriental medicine. We fermented KIOM-MA, the product of KIOM-MA128, using probiotics to improve the therapeutic efficacy via the absorption and bioavailability of the active ingredients. In this study, we demonstrated that KIOM-MA/MA128 exhibited anticolitis effects via the modulation of TJ protein. Interleukin- 6 resulted in a dose-dependent decrease in the TER and an increase in the FITC-dextran permeability; however, pretreatment with $400 \mu \mathrm{g} / \mathrm{ml} \mathrm{KIOM-MA/MA128} \mathrm{resulted} \mathrm{in} \mathrm{a} \mathrm{significant} \mathrm{increase} \mathrm{in}$ the TER and a decrease in the FITC-dextran permeability via IL-6 induction. Furthermore, protein and mRNA TJ levels remained stable after pretreatment with $400 \mu \mathrm{g} / \mathrm{ml}$ KIOM-MA/MA128. Moreover, KIOM-MA/MA128 suppressed the expression of PLC $\gamma 1$ and PKC. Taken together, these findings suggest novel information and clue of the anticolitis effects of KIOM-MA128 via regulation of tight junction.
\end{abstract}

\section{Introduction}

Inflammatory bowel disease (IBD) is composed of two major phenotypes, Crohn's disease (CD) and ulcerative colitis (UC). IBD affects more than 4 million individuals worldwide and frequently results in hospitalization or surgery; however, its molecular pathway remains unclear. The symptoms of IBD include abdominal pain, vomiting, diarrhea, rectal bleeding, and weight loss. Furthermore, IBD increases the risk of colorectal cancer (CRC), depending on the extent and duration of intestinal inflammation [1]. Several studies have suggested that a defective immune system and reduced intestinal function aggravate the pathogenesis of IBD [2].

Cytokines have been directly associated with the pathogenesis of IBD, and they play a critical role in the modulation of intestinal inflammation and the regulation of intestinal permeability [3]. Several lines of evidence suggest that cytokine increases disrupt intestinal barrier function. First, in vitro studies have indicated that IFN- $\gamma$, IL- $1 \beta$, TNF- $\alpha$, and IL- 6 may cause barrier dysfunction in cultured epithelial monolayers [4-6]. In vivo, these cytokines may regulate disease severity and barrier function [7]. Specifically, experimentation with interleukin- 6 has indicated that the regulation of tight junction proteins, such as ZO-1, ZO-2, and $\mathrm{ZO}-3$, occludin, and claudins, increased the paracellular permeability via actin cytoskeleton modulation. Studies have suggested that a connection may exist between IBD and IL6. IL-6 expression was increased in IBD patients [8], and this increased expression level may be related with intestinal barrier function through the discontinuous $\mathrm{TJ}$ and barrier dysfunction in inflammatory intestinal diseases. In addition, the downregulation of claudin-7 expression and the upregulation of claudin- 2 may lead to modifications in the structures of TJs $[9,10]$. In IL-6 (-/-) mice, the induction of acute colitis 
using DSS significantly inhibited the inflammatory response in the colon and decreased body weight loss compared with WT mice [11]. These findings illuminated the role of IL6 signaling in IECs during DSS-induced inflammation and indicated that IL-6 is a key molecule in inflammatory bowel diseases.

In previous years, the treatment of IBD was based on nonspecific suppression of the immune response using corticosteroids or an immunosuppressive, such as azathioprine. Conventional treatment of colitis with an unspecific immune suppressor such as azathioprine may reduce duration of disease and help remission; however, there are severe side effects [12]. Many colitis drugs turn to unconventional treatments in the hopes of reducing the symptoms of disease, and about $40 \%$ of IBD patients use some form of mega-vitamin therapy, including herbal/dietary supplements.

Our group has indicated that KIOM-MA is a specific agent for allergic and chronic inflammatory diseases, and it is composed of several plants, such as Glycyrrhizae radix, Polygoni cuspidati radix, Sophorae radix, Cnidii rhizoma, and Arctii fructus; these herbs have been used in traditional oriental medicine in Asia [13, 14]. We fermented MA, the product of MA128, using probiotics to improve the therapeutic efficacy. The novel herbal medicine KIOM-MA increased the absorption and bioavailability of the active ingredients. Previous studies have demonstrated that MA128 possesses antiatopic dermatitis, antiasthma action, and anticancer [13, 15].

Despite many ongoing researches of integrative medicine and intestinal barrier function, the effect of herbal formula (KIOM-MA/MA128) is still unknown. In present study, we elucidate the effect of KIOM-MA/MA128 on cytokineinduced intestinal barrier dysfunction. Furthermore, we recently demonstrated that KIOM-MA/MA128 exhibited the inhibitory effect of intestinal barrier dysfunction via the regulation of $\mathrm{TJ}$.

\section{Materials and Methods}

2.1. Cell Culture. Caco2 cells (ATCC, Manassas, VA, USA) were grown in EMEM media supplemented with 10\% FBS, 1\% antibiotic solutions $(100,000 \mathrm{U} / \mathrm{L}$ penicillin and $100,000 \mathrm{mg} / \mathrm{L}$ streptomycin) at $37^{\circ} \mathrm{C}$ humidified atmosphere of $5 \% \mathrm{CO}_{2}$. Culture medium was changed every 1-2 days. Upon approximately $90 \%$ confluence, cells were split using $0.25 \%$ trypsin. For growth on filters, Caco 2 cells were plated on Transwell filters and measured TER. For experimental purposes, only Caco 2 cells between passages 30 and 50 were used.

2.2. Reagents. IL-6 was procured from Sigma. Antibodies to occludin, ZO-1, claudin-2, MLC-2, and MLCK were purchased from Zymed Laboratories; the other antibodies were purchased from cell signaling. Alexa 594 secondary antibodies and DAPI (4\#,6\#-diamidino-2-phenylindole) were purchased from Molecular Probes. SYBR-Green PCR Master Mix is ABI (catalog number 43049155; Applied Biosystems). The standard of liquiritin was purchased from Sigma-Aldrich (St. Louis, MO, USA). Nodakenin, quercitrin, arctiin, matairesinol, and icariin were purchased from Chemfaces (Hubei, China). Arctigenin was purchased from MUST (Chengdu Must Bio-Technology Co., Ltd., Chengdu, China). Angoroside C, neolicuroside, (8S, $\left.8^{\prime \prime} \mathrm{R}\right)-8$ (4-hydroxy-3-methoxybenzyl)- $8^{\prime \prime}-\left(3^{\prime}, 4^{\prime}\right.$-dimethoxybenzyl)$\gamma$-butyrolactone 4 -O-( $\beta$-D-glycopyranoside $)$, and emodin 8 -O- $\beta$-D-glucopyranoside 8 were obtained from Chungnam National University (Daejeon, Korea). The purity of the standards was all above 95\%. HPLC grade acetonitrile was purchased from J. T. Baker Inc. (Philipsburg, NJ, USA) and acetic acid purchased from JUNSEI (Junsie Chemical Co., Ltd., Tokyo, Japan). Ultrapure water was prepared by Puris-Evo-UP Water System with Evo-UP Dio VFT and Evo-ROP Dico20 (Mirae ST Co., Ltd., Anyang, Gyeonggi-do, Korea). Ultrapure water (UW) was prepared with a resistivity of $18.2 \mathrm{M} \Omega \mathrm{cm}^{-1}$ (Puris, Esse-UP Water System, Mirae ST Co., Anyang, Korea).

\subsection{Preparation of the Fermented Herbal Cocktail MA128.} The preparation of KIOM-MA128 has been previously described $[15,16]$. Briefly, all herbs for the preparation of MA, including Glycyrrhizae radix, Polygoni cuspidati radix, Sophorae radix, Cnidii rhizoma, and Arctii fructus, were purchased from the Korea Medicinal Herbs Association (Yeongcheon, Korea). The identification of all herbs was confirmed by Professor KiHwan Bae of the College of Pharmacy, Chungnam National University (Daejeon, Korea), and all voucher specimens were deposited in the herbal band in the Korea Institute of Oriental Medicine (KIOM, Korea). MA was fermented at $37^{\circ} \mathrm{C}$ for $48 \mathrm{~h}$ using L. rhamnosus $(1 \times$ $\left.10^{8} \mathrm{CFU} / \mathrm{ml}\right)$, followed by filtration through a $60 \mu \mathrm{m}$ nylon net filter (Millipore, Bedford, MA, USA). Three hundred seventy-six $g$ of MA128 powder was produced, and the yield was $20.44 \%$. The freeze-dried MA128 powder was dissolved in $10 \%(\mathrm{v} / \mathrm{v})$ DMSO in DW. The solution was filtered $(0.2 \mu \mathrm{m}$, pore size) and maintained at $4^{\circ} \mathrm{C}$ prior to use.

Chromatographic Conditions. The KIOM-MA samples and standard samples were analyzed using Dionex HPLC System (Dionex Co., Sunnyvale, CA, USA), equipped with ultimate 3000 series binary pump, an autosampler, a column oven, and a diode array UV/VIS detector (DAD). Data analysis was performed by software named Dionex Chromelon. All chromatographic separations were performed on OptimaPak C18 column $(5 \mu \mathrm{m}, 4.6 \times 250 \mathrm{~mm}$, RS Tech, Daejeon, Korea) and the column temperature was maintained at $40^{\circ} \mathrm{C}$. The mobile phase was consisted of water with $0.2 \%$ acetic acid (A) and acetonitrile with $0.2 \%$ acetic acid (B). The gradient program was set as follows: $10-50 \% \mathrm{~B}$ at $0-60 \mathrm{~min}$ [13]. UV absorption was monitored at $203 \mathrm{~nm}$ and $280 \mathrm{~nm}$ at a flow rate of $1.0 \mathrm{ml} / \mathrm{min}$. The total run time was $60 \mathrm{~min}$, and the injection volume was $5 \mu \mathrm{L}$.

2.4. Preparation of Standard Solutions and Samples. The stock solution of standards was prepared in 100\% methanol at $1 \mathrm{mg} / \mathrm{ml}$. KIOM-MA/MA128 samples were accurately weighted and diluted in methanol:DMSO (90:10, v/v). In all standards, KIOM-MA/MA128 were stored at $4^{\circ} \mathrm{C}$. All working solutions were filtered through a $0.2 \mu \mathrm{m}$ syringe 
membrane filter from Whatman Ltd. (Maidstone, UK) before injection for HPLC analysis.

Cell Viability. Cell viability was analyzed by Cell Counting Kit-8. This assay by utilizing Dojindo's highly water-soluble tetrazolium salt. Briefly, Caco 2 cells $\left(1 \times 10^{3}\right.$ cells) were plated on a 96-filter plate. After IL-6 or KIOM-MA, KIOM-MA128 treatment, add $10 \mu \mathrm{l}$ of the CCK-8 solution to each well of the plate, and incubate it for 1 hour at $37^{\circ} \mathrm{C}$ with $5 \%$ $\mathrm{CO}_{2}$. Absorbance was measured at $450 \mathrm{~nm}$ using a precision microplate reader (Molecular Devices, Sunnyvale, CA).

\subsection{Measurement of Transepithelial Electrical Resistance} (TER). Caco 2 cells were seeded at $1 \times 10^{5}$ cells in culture medium in $0.33 \mathrm{~cm}^{2}$ polyethylene terephthalate membrane inserts with $0.4 \mu \mathrm{m}$ pores (Millipore, Bedford, MA). The medium was changed every 2 days until complete differentiation. The electrical resistance was measured using a Millicell ERS-2 voltohmmeter (Millipore, Bedford, MA). The electrical resistance value was recorded for three consecutive measurements. Caco 2 cells were treated with $50 \mathrm{ng} / \mathrm{ml}$ IL- 6 or untreated following pretreatment with KIOM-MA/MA128, and the transepithelial electrical resistance (TER) was obtained at 18 and $24 \mathrm{~h}$. The TER values were presented as $\mathrm{Ohm} \mathrm{cm}^{2}$ and the experiments were conducted on 3 replicates from three independent experiments.

2.6. Epithelial Paracellular Permeability. The paracellular permeability was measured using a nonabsorbable, FITCconjugated dextran probe ( $\mathrm{FD}-4)$. Caco 2 cells were plated at $1 \times 10^{5}$ cells in culture medium in $0.33 \mathrm{~cm}^{2}$ polyethylene terephthalate membrane inserts with $0.4 \mu \mathrm{m}$ pores (Millipore, Bedford, MA). Following pretreatment, the apical and basolateral sections were washed with PBS. FITC-dextran $(1 \mathrm{mg} / \mathrm{ml})$ was subsequently added to the apical side, and the basolateral side was added to PBS. Following $1 \mathrm{~h}$ of incubation at $37^{\circ} \mathrm{C}, 100 \mu \mathrm{l}$ of media from the basolateral side was plated to a 96-well plate, and the absorbance was measured by a precision microplate reader (Molecular Devices, Sunnyvale, CA). The excitation and emission wavelengths were 490 and $520 \mathrm{~nm}$, respectively.

2.7. Immunofluorescent Staining for Junctional Proteins. Caco 2 cells were seeded at $1 \times 10^{5}$ cells on coverslips. On every 2 days, the medium was changed until full differentiation and cultured 24 hours following treatment with IL-6 and KIOMMA/MA128. After treatment, the Caco2 cell monolayers were washed with the PBS (2 times), fixed using 4\% formaldehyde for $10 \mathrm{~min}$, and permeabilized (0.25\% Triton X-100 in PBS) for $5 \mathrm{~min}$ at room temperature. The blocking was performed with $5 \%$ goat serum for $1 \mathrm{~h}$ at room temperature and incubated at $4^{\circ} \mathrm{C}$ overnight with primary antibody rabbit polyclonal antiZO-1 (1:50, diluted by 5\% goat serum) and then washed with PBS, the incubation of secondary antibody for $1 \mathrm{~h}$ at room temperature (Alexa Fluor 594-anti-rabbit) and DAPI counterstaining. The TJ proteins images were obtained using a fluorescence microscope (OLYMPUS, Japan).
2.8. Western Blot. Western blot analysis was performed. Briefly, $5 \times 10^{5}$ Caco 2 cells per well were plated on 6 well plates. At the $24 \mathrm{~h}$ after treatment, $\mathrm{Caco} 2$ cell monolayers were washed with ice-cold PBS, and cells were lysed with radioimmunoprecipitation assay (RIPA) lysis buffer (Millipore Corporation, Billerica, MA, USA). The supernatant was collected, and amounts of protein were calculated using the BCA Protein Assay Kit. An equal amount of protein was separated on $10 \%$ SDS-PAGE gel. Proteins were transferred to PVDF (polyvinylidene fluoride) membrane (Millipore Corporation, Billerica, MA, USA). The membranes were blocked with $5 \%$ skimmed milk in TBS-T buffer for $1 \mathrm{~h}$ and then incubated with primary antibodies (anti-ZO-1 at 1:200, antioccludin at 1:200, anti-claudin-2 at 1:200, anti-p-MLCK at $1: 1000$, anti-p-PKC $\delta$ at $1: 1000$, anti-p-MLC2 at $1: 1000$, and anti-tubulin at $1: 2000)$ overnight at $4^{\circ} \mathrm{C}$. After being washed in TBS-T buffer, the membranes were incubated with secondary antibodies for $1 \mathrm{~h}$ at room temperature. Protein bands were detected with Immobilon Western substrate (Millipore Corporation, Billerica, USA) and analyzed with the ChemiDoc Touch Imaging System (Bio-Rad, Hercules, CA, USA). The band density was normalized to the reference tubulin.

2.9. Quantitative Real-Time PCR. $1 \times 10^{5}$ Caco 2 cells per well were plated in 6-well tissue culture-treated plates. At the end of the experiment, RNA was obtained using TRIzol reagent and chloroform. Reverse transcription was conducted in a $20 \mu \mathrm{l}$ reaction with $1 \mu \mathrm{g}$ of total RNA transformed into cDNA using AccuPower Cycle Script RT Premix (Bioneer). The measurements of ZO-1, ZO-2, and ZO-3, claudin-1, claudin-2, and claudin-7, occludin, and $\beta$-actin mRNA were conducted under the following conditions: 45 cycles of $95^{\circ} \mathrm{C}$ for $10 \mathrm{~s}, 60^{\circ} \mathrm{C}$ for $20 \mathrm{~s}$, and $72^{\circ} \mathrm{C}$ for $30 \mathrm{~s}$ using a LightCycler 480 II (Roche, Rotkreuz, SWI). The mRNA level in each sample was quantified using the cycle threshold $(\mathrm{Ct})$ value. The target genes were normalized relative to the reference gene actin.

2.10. Statistical Analysis. All statistical analyses were performed with SPSS version 18 and graphs were drawn with GraphPad Prism version 5. Experimental values are given as the means \pm SEM. The statistical difference was determined by one-way ANOVA test. $p$ values smaller than 0.05 were regarded as statistically significant.

\section{Results}

3.1. HPLC Analysis. Eleven marker compounds of KIOMMA and KIOM-MA128 liquiritin (tR $16.7 \mathrm{~min}$ ), nodakenin (tR $18.6 \mathrm{~min}$ ), quercitrin ( $\mathrm{tR} 22.3 \mathrm{~min}$ ), angoroside $\mathrm{C}$ ( $\mathrm{tR}$ $23.9 \mathrm{~min}$ ), neolicuroside (tR $26.2 \mathrm{~min}$ ), arctiin (tR $27.2 \mathrm{~min}$ ), (8S, $\left.8^{\prime \prime} \mathrm{R}\right)$-8-(4-hydroxy-3-methoxybenzyl)- $8^{\prime \prime}$ - $\left(3^{\prime}, 4^{\prime}\right.$-dimethoxybenzyl)- $\gamma$-butyrolactone 4 -O- $(\beta$-D-glucopyranoside) (tR $28.9 \mathrm{~min}$ ), emodin 8 -O- $\beta$-D-glucopyranoside (tR $30.5 \mathrm{~min}$ ), matairesinol (tR $31 \mathrm{~min}$ ), icariin (tR $36 \mathrm{~min}$ ), and arctigenin ( $\mathrm{tR}$ $37.2 \mathrm{~min}$ ) were identified via HPLC analysis and compared with standard compounds (Figure 1(a), Table 1). Following fermentation, nodakenin ( $\mathrm{tR} 18.6 \mathrm{~min}$ ), quercitrin ( $\mathrm{tR}$ 
TABLE 1: List of the changed eleven markers and peak areas from KIOM-MA/MA128.

\begin{tabular}{|c|c|c|c|}
\hline Number & Compound name & $\begin{array}{l}\text { KIOM-MA area } \\
(\mathrm{mAU})\end{array}$ & $\begin{array}{c}\text { KIOM-MA128 } \\
\text { area }(\mathrm{mAU})\end{array}$ \\
\hline 1 & Liquiritin & 4.41 & 4.57 \\
\hline 2 & Nodakenin & 16.35 & 14.84 \\
\hline 3 & Quercitrin & 22.77 & 13.93 \\
\hline 4 & Angoroside C & 3.89 & 6.48 \\
\hline 5 & Neolicuroside & 0.31 & 0.21 \\
\hline 6 & Arctiin & 233.51 & 246.11 \\
\hline 7 & $\begin{array}{c}\left(8 \mathrm{~S}, 8^{\prime \prime} \mathrm{R}\right)-8-(4-\text {-hydroxy-3- } \\
\text { methoxybenzyl })-8^{\prime \prime}-\left(3^{\prime}, 4^{\prime}-\right. \\
\text { dimethoxybenzyl })-\gamma \text {-butyrolactone } \\
\text { 4-O- }(\beta \text {-D-glucopyranoside })\end{array}$ & 0 & 2.24 \\
\hline 8 & Emodin 8 -O- $\beta$-D-glucopyranoside & 2.66 & 2.57 \\
\hline 9 & Matairesinol & 1.37 & 3.19 \\
\hline 10 & Icariin & 5.64 & 6.37 \\
\hline 11 & Arctigenin & 3.8 & 14.34 \\
\hline
\end{tabular}

$22.3 \mathrm{~min}$ ), and neolicuroside (tR $26.2 \mathrm{~min}$ ) were decreased, and the remaining compounds were increased in KIOMMA128 (fermented KIOM-MA) following deglycosylation during fermentation. The structures of the KIOM-MA and KIOM-MA128 compounds are presented in Figure 1(b).

Effects of IL-6 and KIOM-MA/MA128 on Cell Viability. We evaluated the effects of IL-6, KIOM-MA, and KIOM-MA128 on the cell viability in $\mathrm{Caco} 2$ monolayers. The $\mathrm{Caco} 2$ cell viability was measured following treatment with various concentrations of KIOM-MA/MA128 (100-400 $\mu \mathrm{g} / \mathrm{ml})$ and incubation for $24 \mathrm{~h}$. The findings indicated that KIOMMA/MA128 with/without IL-6 did not affect the cell viability in the Caco 2 monolayers ( $p>0.05$, Figure 2$)$.

3.2. KIOM-MA/MA128 Prevented IL-6-Induced Epithelial Barrier Dysfunction in Caco2 Cell Monolayers. Epithelial barrier dysfunction was measured as the flux of the FITCdextran, and the TER was measured. Interleukin-6 resulted in a dose-dependent decrease in the TER (increase in the permeability) in the range of 10 and $50 \mathrm{ng} / \mathrm{ml}$, with a maximal decrease in the TER at $24 \mathrm{~h}$. Pretreatment with $400 \mu \mathrm{g} / \mathrm{ml}$ of KIOM-MA and KIOM-MA128 resulted in a significant increase in the TER and a decrease in the FITC-dextran permeability via IL-6 induction. KIOM-MA128 exhibited a more substantial effect on the TER value and the FITC-dextran permeability compared with KIOM-MA (Figure 3(a)). The distribution of the protein ZO-1 was determined via an immunofluorescence assay using confocal microscopy (Figure 3(b)). ZO-1 was localized at the cell membrane as a continuous encircling band at the cellular borders in normal condition. The distribution of ZO-1 was disturbed and exhibited an irregular circling band at the cell membrane by IL6 and pretreatment with KIOM-MA/MA128 prevented the disruption of ZO-1 in the Caco2 cell monolayer (Figure 3(c)). The expression level of ZO-1 was decreased in the IL-6treated cells in cell lysate (Figure 3(d)). These morphological changes correlated with the results of the FITC-dextran permeability as manifested by the TER. Our findings also indicate that KIOM-MA128 may more effectively protect intestinal function via IL-6-mediated barrier dysregulation compared with KIOM-MA.

3.3. Effects of KIOM-MA/MA128 on IL-6-Induced Tight Junctional Protein Expression. To examine the effect of KIOMMA/KIOM-MA128 on IL-6-induced TJ disruption, Caco2 cells were pretreated with $400 \mu \mathrm{g} / \mathrm{ml}$ KIOM-MA/KIOMMA128 for $1 \mathrm{~h}$ and incubated with IL- 6 for $24 \mathrm{~h}$. We analyzed the expression of tight junction proteins, including ZO-1, occludin, and claudin-2, via Western blot. The expression levels of occludin and ZO-1 were substantially decreased in the IL-6-treated cells. The cotreated KIOM-MA/MA128 cells exhibited an increased expression of ZO-1 and occludin. Moreover, the level of claudin-2 expression was significantly increased in the IL-6-treated cells. The cotreated KIOMMA/MA128 cells exhibited an attenuated level of claudin-2 expression (Figure 4(a)). Our findings indicate that KIOMMA/MA128 reduced the IL-6-induced disruption of TJ proteins, and KIOM-MA128 was more effective in providing protection compared with KIOM-MA.

3.4. Effects of KIOM-MA/MA128 on IL-6-Induced Tight Junctional $m R N A$ Expression. We investigated the effects of KIOM-MA/MA128 on the mRNA levels of TJ proteins following IL-6 treatment using real-time PCR analysis. The Caco 2 cells were pretreated with $400 \mu \mathrm{g} / \mathrm{ml}$ KIOM-MA and KIOM-MA128 for $1 \mathrm{~h}$ and evaluated TJ-mediated mRNA, including ZO-1, ZO-2, and ZO-3 and occludin. The claudin family levels, such as claudin-1 and claudin-7, were decreased, whereas claudin- 2 was increased in the IL-6-induced expression, and pretreatment of KIOM-MA/MA128 was downregulated. Furthermore, KIOM-MA128 demonstrated a more significant effect on TJ-mediated mRNA expression compared with the nonfermented KIM-MA (Figure 4(b)). 


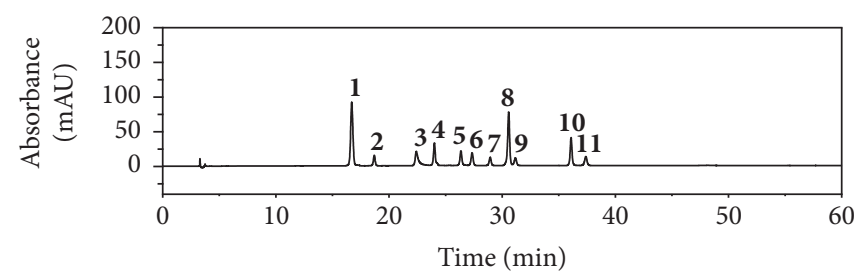

(A) Standard mixture $280 \mathrm{~nm}$

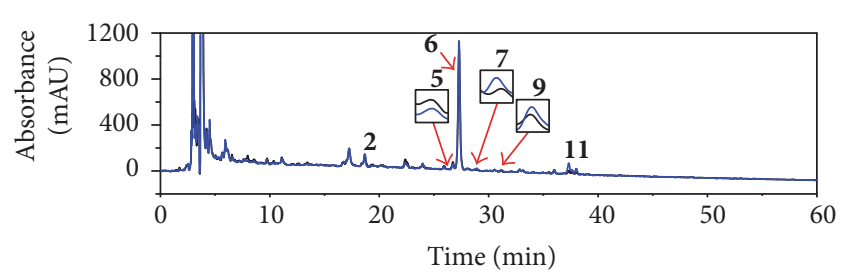

KIOM-MA-CON

— KIOM-MA-128

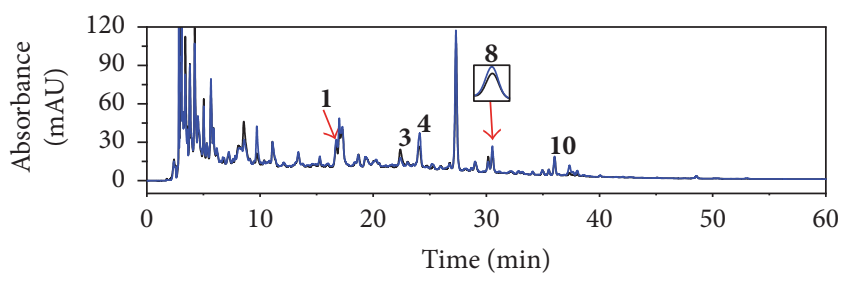

KIOM-MA-CON

KIOM-MA-128

(C) KIOM-MA sample $280 \mathrm{~nm}$

(a)<smiles>O=C1CC(c2ccc(OC3O[C@H](CO)[C@@H](O)[C@H](O)[C@H]3O)cc2)Oc2cc(O)ccc21</smiles>

(1) Liquiritin<smiles>COc1ccc(CCOC2OC(CO[C@H]3OC[C@@H](O)[C@H](O)[C@H]3O)C(OC(=O)/C=C/c3ccc(O)c(OC)c3)[C@H](O[C@@H]3OC(C)[C@H](O)[C@H](O)[C@H]3O)[C@@H]2O)cc1O</smiles>

(4) Angoroside C<smiles>COc1ccc(CC2(C)COC(=O)C2(C)Cc2ccc(O[C@@H]3O[C@H](O)[C@@H](O)[C@H](O)[C@H]3O)c(OC)c2)cc1OC</smiles>

(7) (8S, $\left.8^{\prime \prime} \mathrm{R}\right)$-8-(4-hydroxy-3-methoxybenzyl)-

$8^{\prime \prime}-\left(3^{\prime}, 4^{\prime}\right.$-dimethoxybenzyl $)-\gamma$-butyrolactone 4 $\mathrm{O}-(\beta$-D-glucopyranoside)<smiles>O=C(/C=C/c1ccc(O[C@@H]2O[C@H](CO)[C@@H](O)[C@H](O)[C@H]2O[C@@H]2OC[C@@H](CO)[C@H]2O)cc1)c1ccc(O)cc1O</smiles>

(5) Neolicuroside<smiles>O=C1c2cc(CO)cc(O)c2C(=O)c2c(O[C@@H]3O[C@H](CO)[C@@H](O)[C@H](O)[C@H]3O)cccc21</smiles>

(8) Emodin 8-O- $\beta$-D-glucopyranoside<smiles>C[C@@H]1O[C@@H](Oc2c(-c3ccc(O)c(O)c3)oc3cc(O)cc(O)c3c2=O)[C@H](O)[C@H](O)[C@@H]1O</smiles>

(3) Quercitrin

(6) Arctiin<smiles>COc1cc(C[C@@H]2COC(=O)[C@H]2Cc2ccc(O)c(OC)c2)ccc1O</smiles>

(9) Matairesinol

Figure 1: Continued. 
<smiles>COc1ccc(-c2oc3c(CCC(C)C)c(O[C@@H]4O[C@H](CO)[C@@H](O)[C@H](O)[C@H]4O)cc(O)c3c(=O)c2O[C@@H]2C[C@H](C)[C@@H](O)[C@H](O)[C@H]2O)cc1</smiles>

(10) Icariin

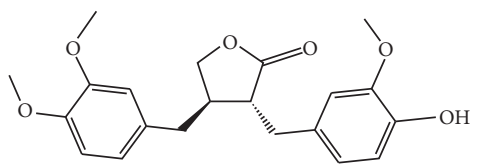

(11) Arctigenin

(b)

FIgURE 1: The HPLC chromatogram and the chemical structure of eleven markers of KIOM-MA/MA128. (a) The HPLC chromatogram of KIOM-MA/MA128. (b) The chemical structure of eleven markers of KIOM-MA/MA128.

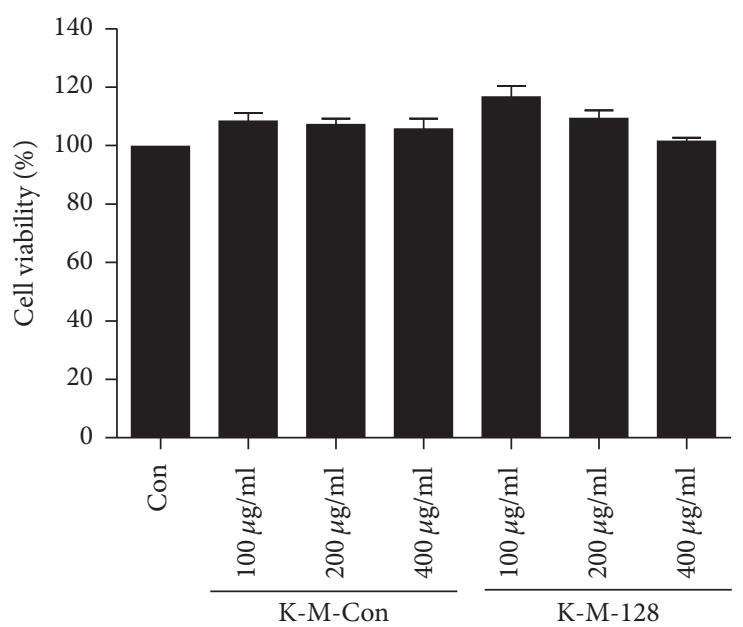

(a)

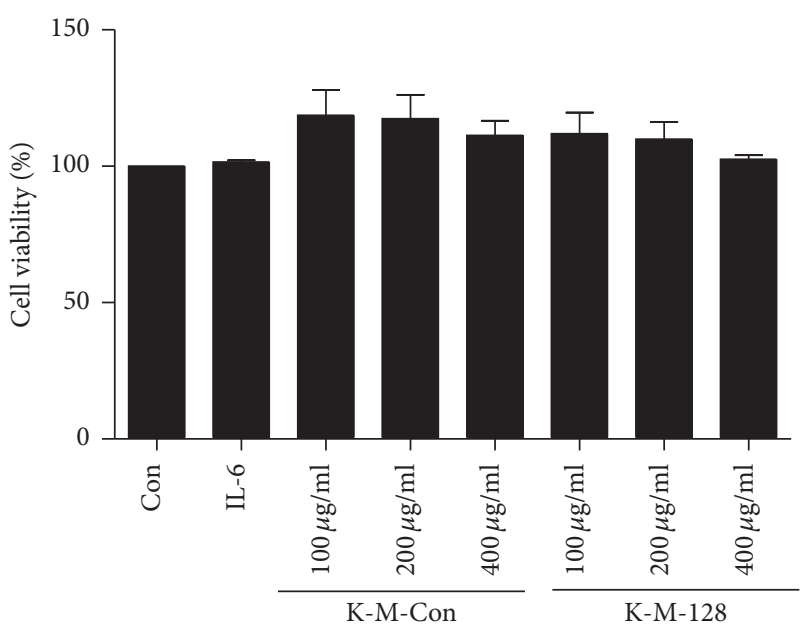

(b)

FIGURE 2: Effects of IL-6 and KIOM-MA/MA128 on cell viability of Caco2 cells. Cells were pretreated with various concentrations (100$400 \mu \mathrm{g} / \mathrm{ml})$ of KIOM-MA/MA128 for $1 \mathrm{~h}$ and treated with IL-6 $(50 \mathrm{ng} / \mathrm{ml})$ for $24 \mathrm{~h}$. Cell viability was determined using a Cell Counting Kit-8. Cell viability is represented as the percentage relative absorbance compared with the controls. (a) Cell viability of KIOM-MA/MA128; (b) cell viability of KIOM-MA/MA128 with IL-6 $(50 \mathrm{ng} / \mathrm{ml})$. The results are represented as the means \pm SDs of three independent experiments, and $t$-tests were performed.

3.5. KIOM-MA128 Protected Caco2 Monolayer Barrier Function via Suppression of PLC 1 1-PKC Pathway. To examine the effect of KIOM-MA/MA128 on the cytoskeleton of Caco2 cells, a Western blot analysis was performed on cells treated with $400 \mu \mathrm{g} / \mathrm{ml} \mathrm{KIOM-MA/MA128}$ for $24 \mathrm{~h}$. As shown in Figure 5(a), the IL-6-treated cells increased the expression level of p-PLC $\gamma 1$ (y783) at $30 \mathrm{~min}$ and decreased at $60 \mathrm{~min}$. However, pretreatment with $400 \mu \mathrm{g} / \mathrm{ml}$ KIOM-MA/MA128 for $1 \mathrm{~h}$ prior to IL-6 significantly decreased the IL-6-induced activation of p-PLC $\gamma 1$ (y783). Furthermore, we assessed the MLCK pathway signaling to examine the epithelial barrier protection of KIOM-MA/MA128 by IL-6-induced epithelial barrier dysfunction. The pretreatment of $\mathrm{Caco} 2$ cells with KIOM-MA/MA128 for $1 \mathrm{~h}$ decreased the expression levels of p-PKC, MLCK, and p-MLC2 (Figure 5(b)). Furthermore, our findings indicate that KIOM-MA128 demonstrated a substantially stronger reducing effect on disruption of cytoskeleton by blocking the PLC $\gamma 1$-PKC pathway compared with KIOM-MA.

\section{Discussion}

Many studies regarding natural herbal medicines have demonstrated the therapeutic potential of natural products in intestinal barrier function protection [17, 18]. Furthermore, our previous studies have demonstrated that KIOM-MA/MA18 have anti-inflammatory, anticancer, and antiatopic effects [13-15]. In this study, we analyzed the active ingredients of KIOM-MA/MA128 via HPLC and identified the altered eleven ingredients (Table 1).

Fermentation changes the decomposition of organic matter via microorganisms and produces numerous micromolecules from macromolecules. Many studies have demonstrated that fermentation by microorganisms improves the 

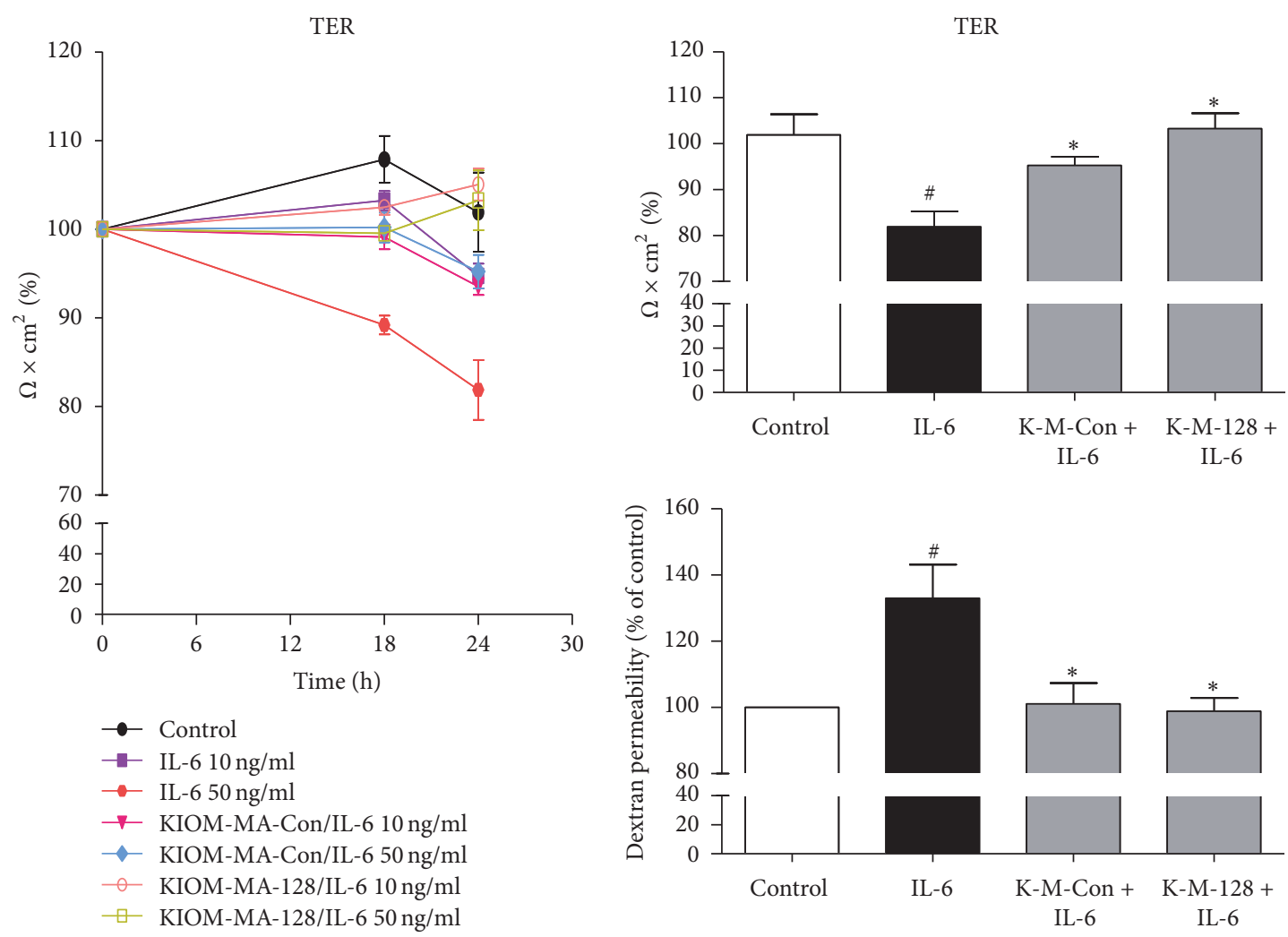

(a)
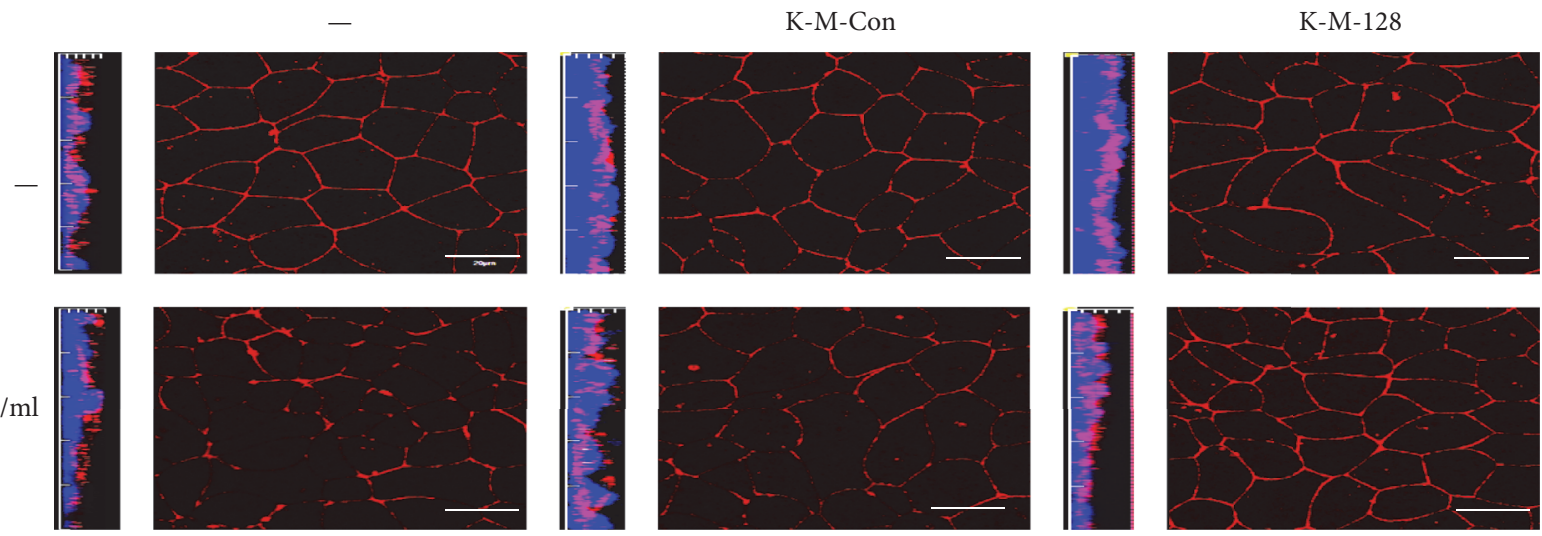

(b)

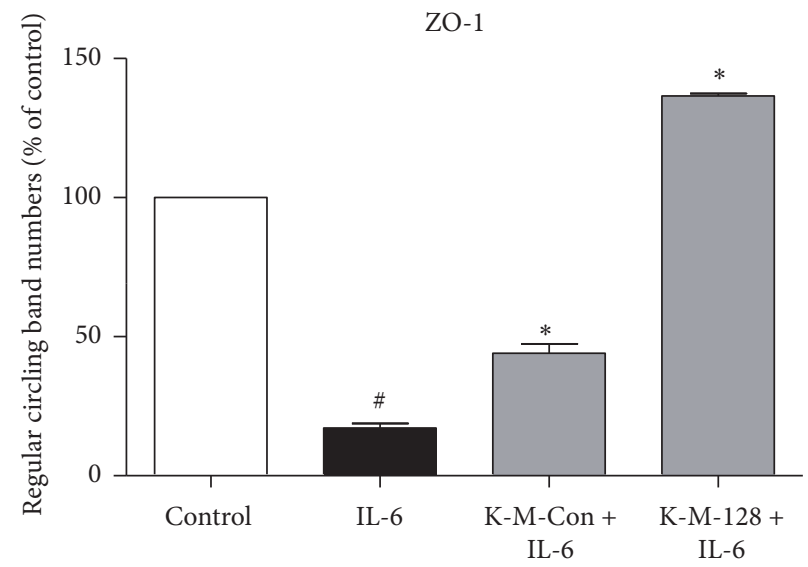

(c)

Figure 3: Continued. 


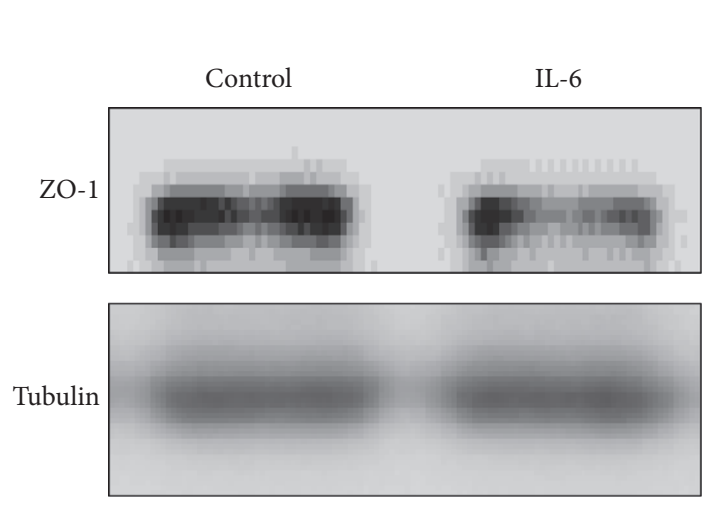

(d)

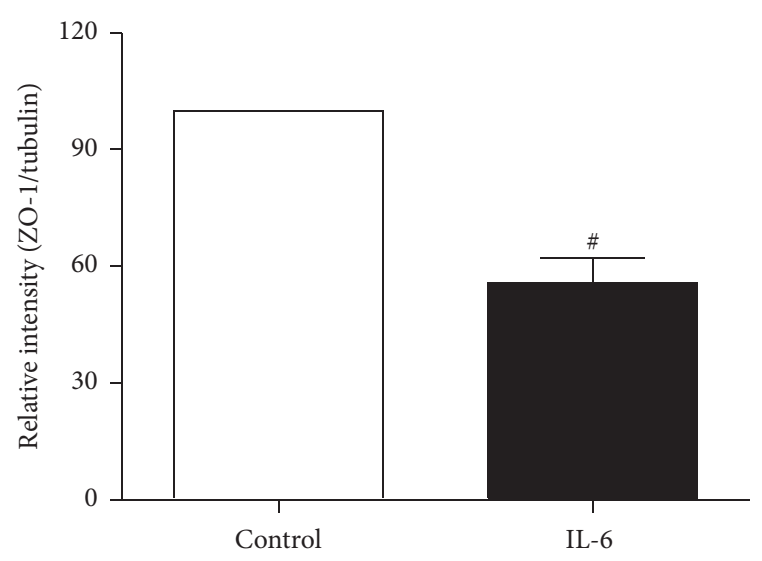

FIGURE 3: Effects of KIOM-MA/MA128 on Caco2 monolayer intestinal barrier function. (a) Intestinal barrier function was analyzed via the TER value, and paracellular permeability was determined using a nonabsorbable, fluorescein isothiocyanate- (FITC-) conjugated dextran probe (FD-30). Caco 2 monolayer cells were pretreated with $400 \mu \mathrm{g} / \mathrm{ml} \mathrm{KIOM-MA/MA128} 1 \mathrm{~h}$ prior to IL-6 (10 ng/ml and $50 \mathrm{ng} / \mathrm{ml}) \mathrm{exposure}$ for $24 \mathrm{~h}$. (b) Caco 2 monolayer cells were pretreated with $400 \mu \mathrm{g} / \mathrm{ml} \mathrm{KIOM-MA/MA128} 1 \mathrm{~h}$ prior to IL-6 (50 ng/ml) exposure for $24 \mathrm{~h}$. ZO-1 was detected via immunofluorescence microscopy. Treatment of IL- 6 caused significant disruptions of ZO-1. The ZO-1 staining was decreased in intensity and exhibited an irregular band. Four hundred $\mu \mathrm{g} / \mathrm{ml}$ KIOM-MA128 completely prevented ZO-1 in IL-6 treated Caco 2 monolayers. (c) Histograms are represented by continuous bands encircling the cells at the cellular borders. (d) Cell lysates were analyzed for ZO-1 expression via Western blot. The results are reported as the means \pm SDs from 3 independent experiments. ${ }^{*} p<0.05$ compared with the IL- 6 treated group; ${ }^{\#} p<0.05$ compared with the control group.

therapeutic efficacy, such as the absorption and bioavailability of the active ingredients [19-21]. Our findings demonstrated that arctigenin, arctiin, icariin, and matairesinol were increased, whereas nodakenin, neolicuroside, and quercitrin were decreased following fermentation (Figure 1). Arctigenin, arctiin, and matairesinol reinforced the intestinal barrier function through the regulation of paracellular permeability [22]. Moreover, icariin inhibited permeability in sertoli cells and the regulation of TJ proteins in pyramidal neurons $[23,24]$. Here, we used KIOM-MA128, the fermentation of KIOM-MA, to determine whether it facilitated improvements in the protective effects on intestinal barrier dysfunction via the inhibition of actin cytoskeletal rearrangement.

The incidence rate of inflammatory bowel disease has continuously increased worldwide; however, its molecular pathway remains incompletely understood. Patients with Crohn's disease (CD) and ulcerative colitis (UC) exhibit increased intestinal permeability because of intestinal inflammation by external stimuli, such as pathogens, toxins, and other antigens. The entry of external pathogenesis induced the inflammatory response within the immune system, including mast cells and lymphocytes, and subsequently upregulated various cytokines, such as TNF-a, IL-1b, and IL-6. These cytokines increased the intestinal permeability through the downregulation of TER in intestinal epithelial cells. Our findings demonstrated that IL-6 disrupted the paracellular permeability and TER value; however, KIOMMA/MA128 inhibited the penetration of FITC-dextran and reversed the decreasing TER value (Figure 3(a)).

TJs are not static barriers but are highly dynamic structures and cytoplasmic scaffolding proteins, such as ZO-1, $\mathrm{ZO}-2$, and $\mathrm{ZO}-3$, that act to anchor the actin cytoskeleton
[25], which plays a critical role in TJ structure and function. These TJ proteins modulate homeostasis in the intestinal tract through the regulation of nutrients, ions, and water entry. IL6 was increased in IBD patients and modulated the expression of ZO- 1 and claudin-2 proteins in vivo and in vitro. This study indicated the anticolitis effect of KIOM-MA/MA128 using IL-6-mediated intestinal barrier dysfunction in the Caco2 cell monolayer. Our findings demonstrated that KIOMMA/MA128 increased the mRNA levels of ZO-1, ZO-2, and ZO-3, occludin, and claudin- 1 and claudin-7 and decreased the mRNA level of claudin-2 following IL-6-induced dysregulation of the mRNA levels of TJ proteins (Figure 4(b)). Furthermore, IL- 6 treated cells downregulated the ZO- 1 and occludin expression; however, pretreatment with KIOMMA/MA128 protected these proteins (Figure 4(a)).

Cytokine-induced changes in paracellular permeability contribute to diverse pathological and physiological conditions, which are caused by the regulation of intestinal barrier integrity. Cytokines, including IFN $-\gamma$, TNF- $\alpha$, and interleukins, affect the actin-myosin cytoskeleton linked by scaffolding proteins [26]. In TJ regulation signaling pathways, the relationships between TJ proteins and the actomyosin ring are regulated by diverse signaling proteins, such as mitogen-activated protein kinases (MAPK), protein kinase C (PKC), myosin light chain kinase (MLCK), and the GTPases. Furthermore, PLC $\gamma 1$ plays a role in actin reorganization via the inhibition of PKC pathway and $\mathrm{Ca}^{2+}$ signaling [27-29]. $\mathrm{PKC}$ isoforms have also been indicated to modulate the TER value in intestinal epithelial cell monolayers [30]. The activations of PKC $\alpha$ and PKC $\delta$ lead to the activation of MLCK and increase the TER value, paracellular permeability, and redistribution of ZO-1. The phosphorylation of myosin 

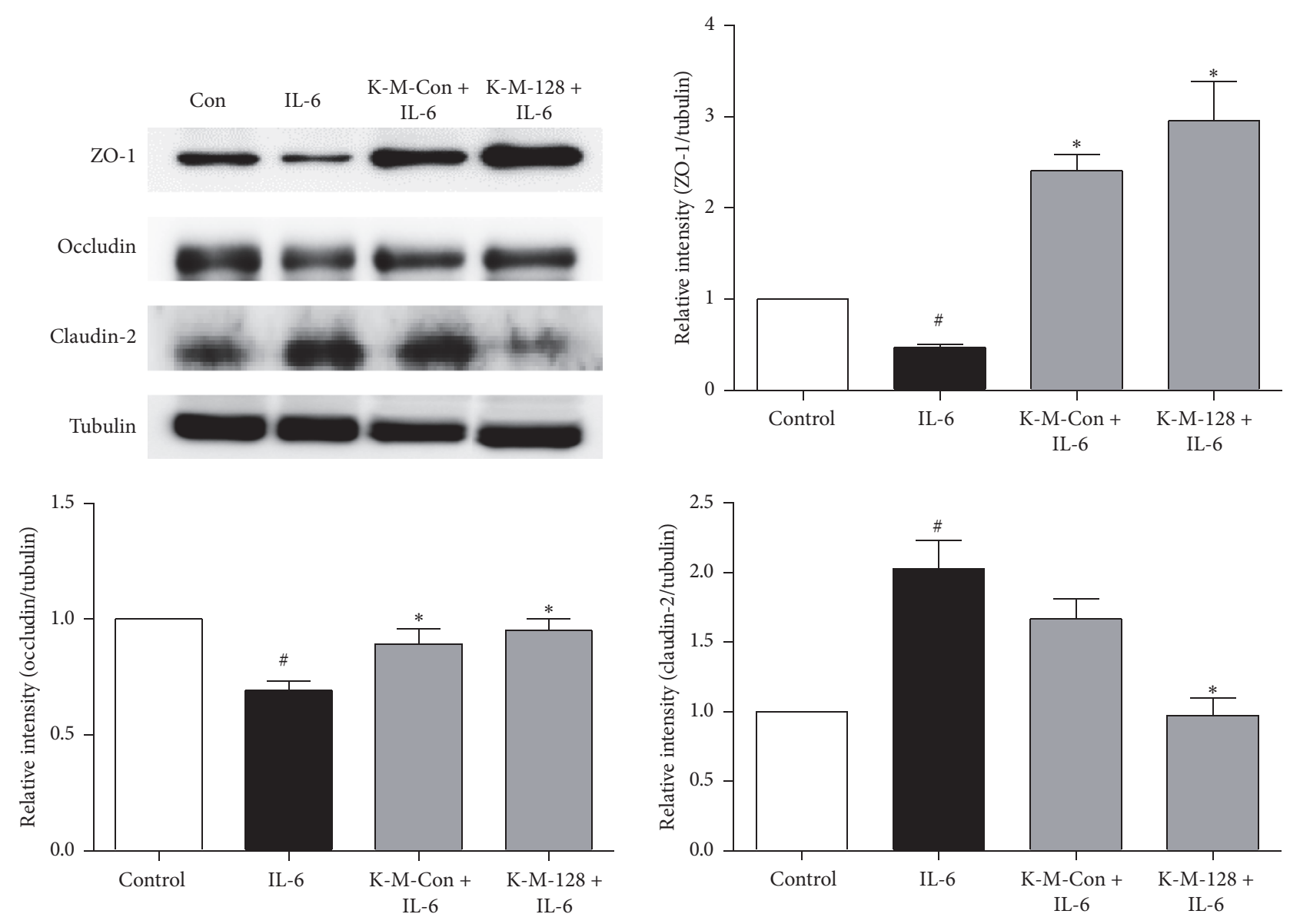

(a)
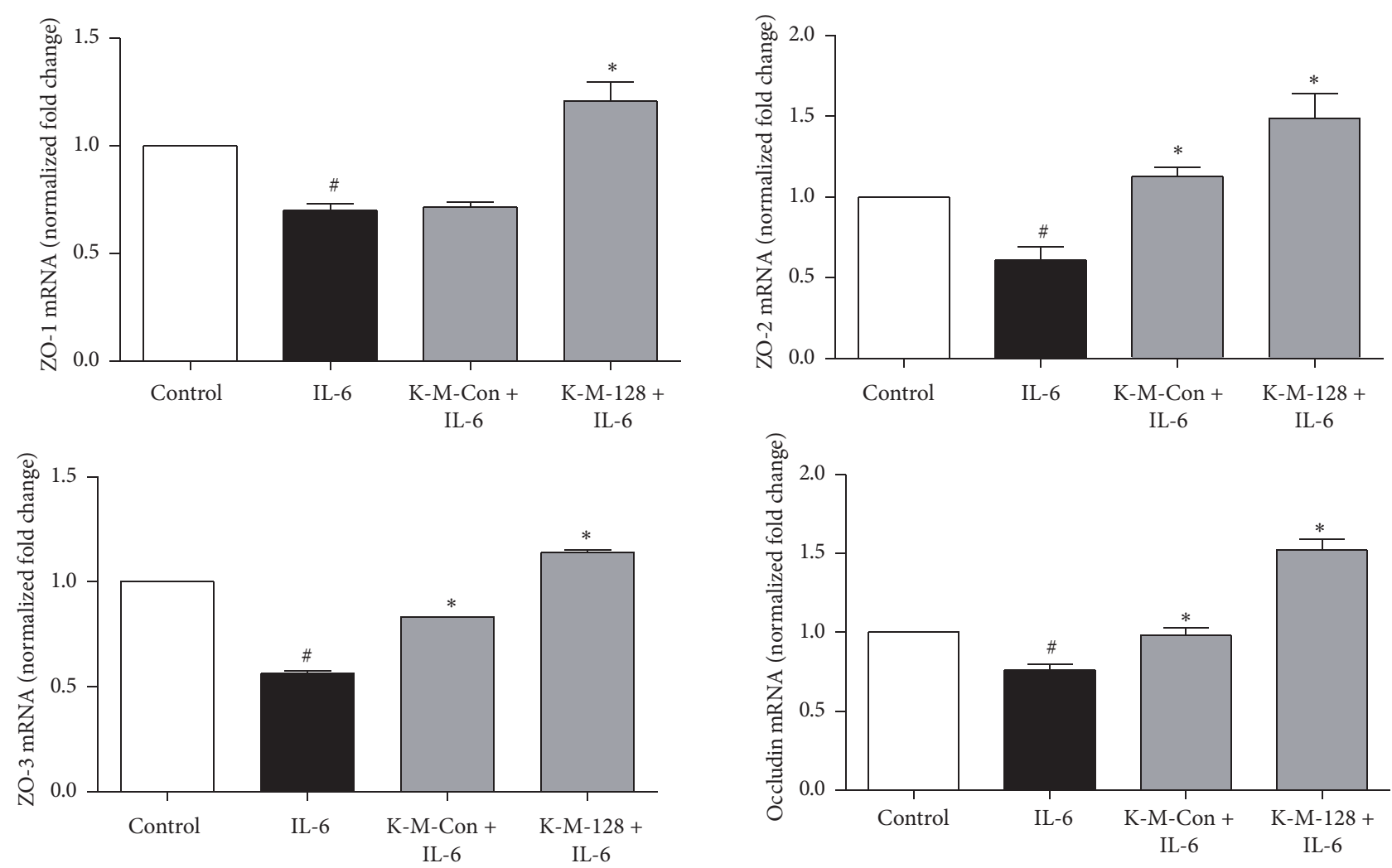

Figure 4: Continued. 

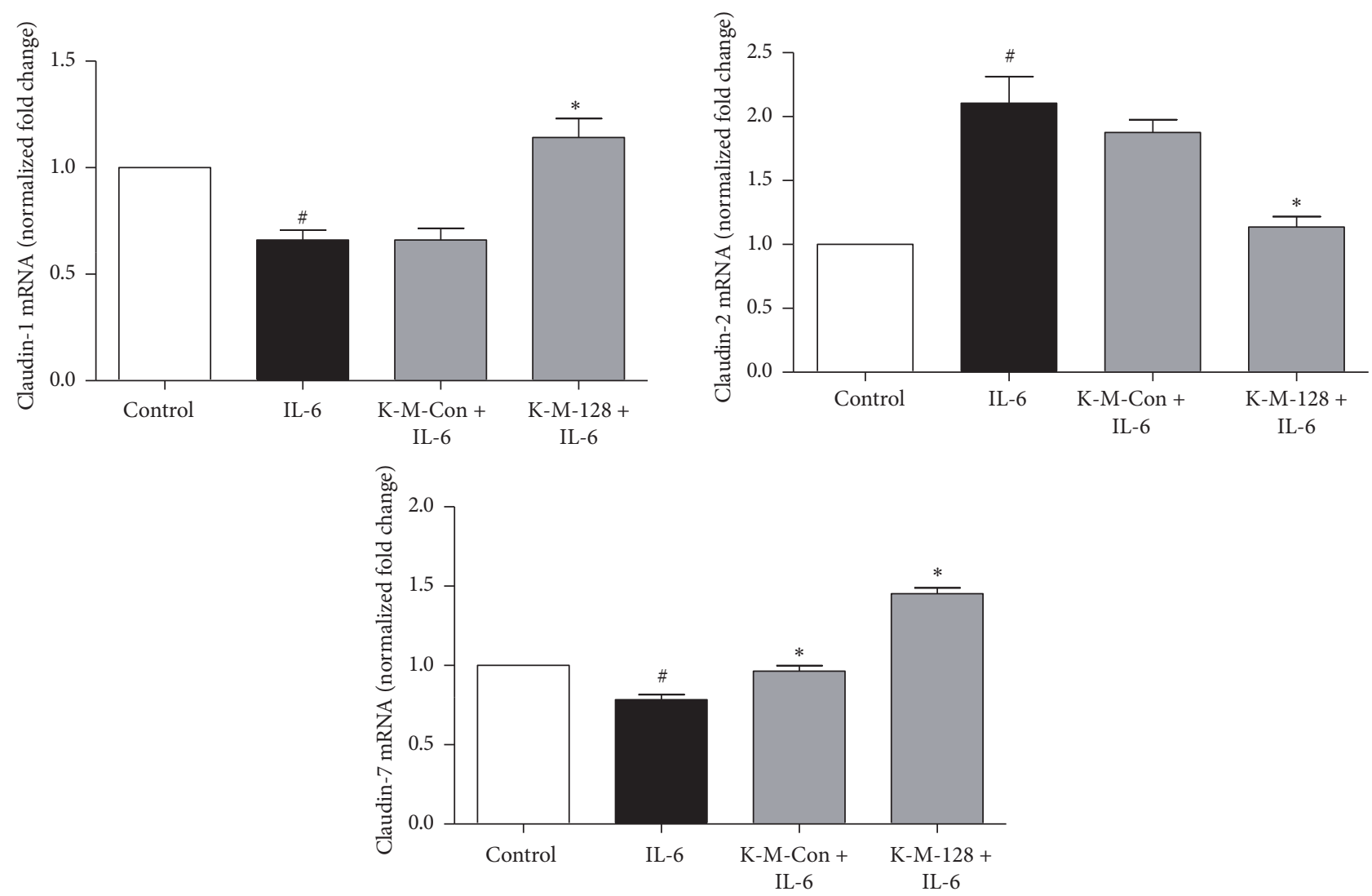

(b)

Figure 4: Effects of KIOM-MA/MA128 on the mRNA and protein expression of TJ proteins in the Caco2 monolayer. Caco2 monolayer cells were pretreated with $400 \mu \mathrm{g} / \mathrm{ml} \mathrm{KIOM-MA/MA128} 1 \mathrm{~h}$ prior to IL-6 (50 ng/ml) exposure for $24 \mathrm{~h}$. (a) Cells were lysed, and the lysates were examined via Western blot for ZO-1, occludin, and claudin-2. Pretreatment with KIOM-MA/MA128 protected the TJ proteins. (b) Total mRNA was isolated, and the mRNA levels of TJ proteins, such as ZO-1, ZO-2, and ZO-3, occludin, and claudin-1, claudin-2, and claudin-7, were assessed. Pretreatment with KIOM-MA/MA128 protected the IL-6-induced mRNA expression. The results are reported as the means \pm SDs from 3 independent experiments. ${ }^{*} p<0.05$ compared with the IL- 6 treated group; ${ }^{*} p<0.05$ compared with the control group.

II regulatory light chain (MLC) by MLCK plays a pivotal role in contractions in the actomyosin ring. The inhibition of MLCK prevents increases in TJ permeability [31]. MLCK-mediated regulation of TJ permeability by diverse extracellular stimuli, such as cytokines and bacteria, is a critical pathway to maintain the TJ barrier $[32,33]$. The phosphorylation of MLC is also associated with the assembly and disassembly of TJs. In a recent study, the upregulation of MLCK expression in differentiated Caco 2 cell monolayers led to a reduction in the TER and redistribution of ZO-1 and occludin $[34,35]$. Our data demonstrated that IL-6 increased the paracellular permeability through the activation of $\mathrm{PKC} \delta$, MLCK, and p-MLC2 via the activation of PLC $\gamma 1$; however, KIOM-MA/MA128 inhibited the activation of PLC $\gamma 1, \mathrm{PKC} \delta$, MLCK, and p-MLC2 in the Caco2 cell monolayer (Figures $5(a)$ and $5(b))$.

\section{Conclusions}

These findings provide crucial results that KIOM-MA/ MA128 prevented IL-6-induced colitis through the regulation of TJ proteins, and these findings were correlated with MLCK inhibition. Additional investigations are necessary to understand the molecular mechanism of KIOM-MA/MA128 in the interrelation with intestinal barrier function. In conclusion, our study suggests that KIOM-MA and KIOM-MA128 protect the IL-6-induced TJ dysfunction in the Caco2 cell monolayer through the upregulation of $\mathrm{ZO}$ proteins ( $\mathrm{ZO}-$ $1, \mathrm{ZO}-2$, and ZO-3), occludin, and claudin-1 and claudin-7, as well as the downregulation of claudin-2, p-PKC $\delta$, MLCK, and $\mathrm{p}-\mathrm{MLC} 2$ via a PLC $\gamma 1$-dependent pathway. These findings provide alternative targets in the treatment of IBD, and KIOM-MA128 is more effective for the treatment of IBD compared with KIOM-MA. Finally, the current findings provide support for the anticolitis effects of KIOM-MA128 in regard to pharmacological evidence.

\section{Competing Interests}

The authors declare that they have no conflict of interests. 

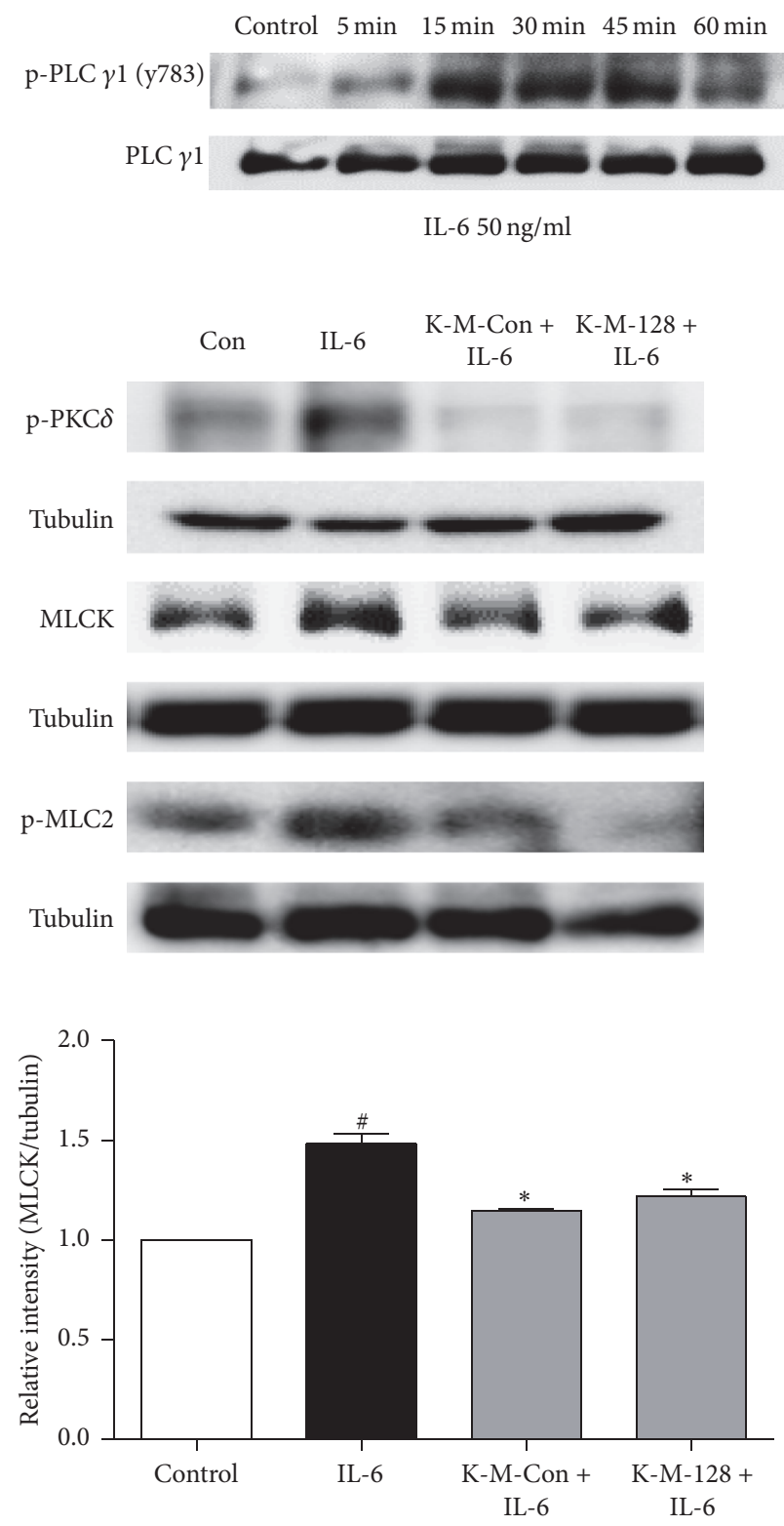

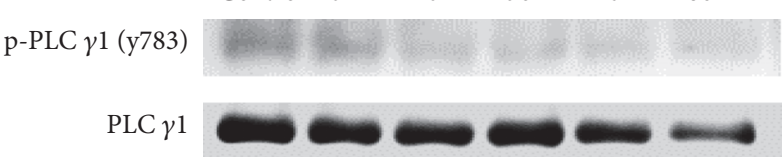

IL-6 $50 \mathrm{ng} / \mathrm{ml}+\mathrm{K}-\mathrm{M}-128$

(a)
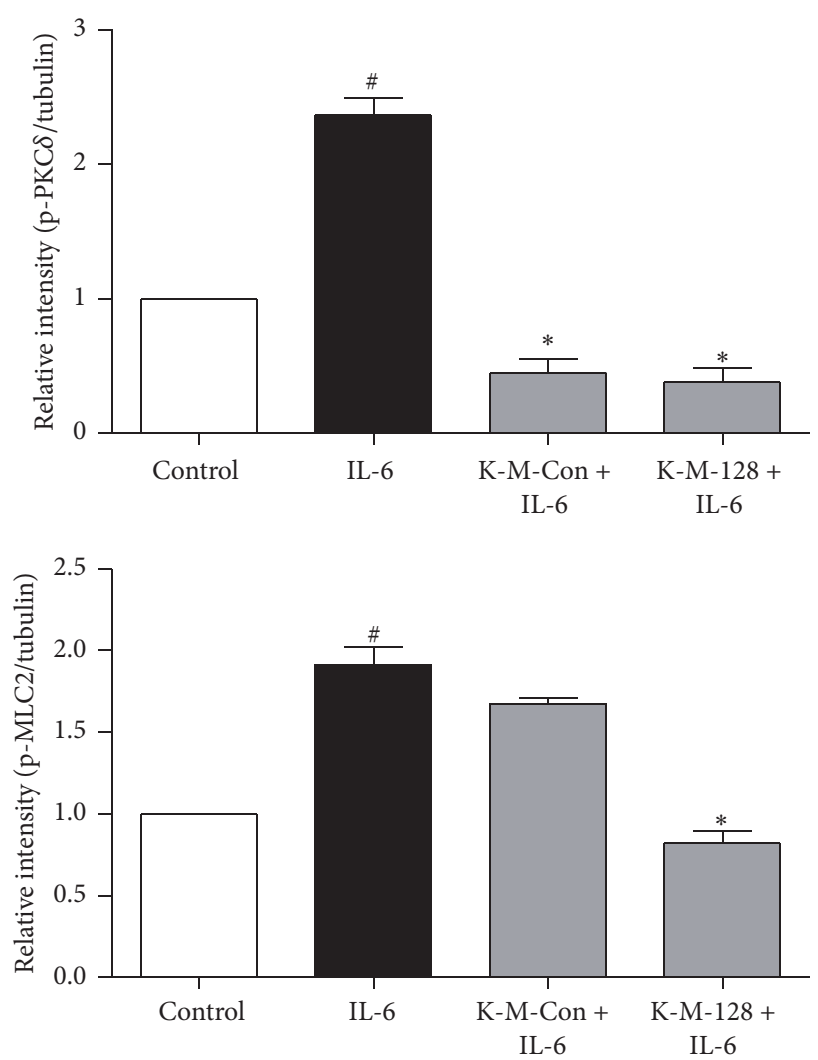

(b)

FIgURE 5: KIOM-MA/MA128 prevent the disruption of cytoskeleton by IL-6. (a) KIOM-MA/MA128 inhibited the IL-6-induced activation of PLC $\gamma 1$. (b) Lysates were assayed for MLCK, MLC2, and PKC $\delta$ via Western blot. KIOM-MA/MA128 prevented the activation of MLCK, MLC2, and PKC $\delta$ induced by IL- 6 . The results are reported as the means \pm SDs from 3 independent experiments. * $p<0.05$ compared with the IL- 6 treated group; ${ }^{\#} p<0.05$ compared with the control group.

\section{Acknowledgments}

This work was supported by a Grant (no. K16281) from the Korea Institute of Oriental Medicine funded by the Ministry of Science, ICT, and Future Planning, Republic of Korea.

\section{References}

[1] A. Kaser, S. Zeissig, and R. S. Blumberg, "Inflammatory bowel disease," Annual Review of Immunology, vol. 28, pp. 573-621, 2010.
[2] B. Khor, A. Gardet, and R. J. Xavier, "Genetics and pathogenesis of inflammatory bowel disease," Nature, vol. 474, no. 7351, pp. 307-317, 2011.

[3] M. F. Neurath, "Cytokines in inflammatory bowel disease," Nature Reviews Immunology, vol. 14, no. 5, pp. 329-342, 2014.

[4] M. Bruewer, M. Utech, A. I. Ivanov, A. M. Hopkins, C. A. Parkos, and A. Nusrat, "Interferon- $\gamma$ induces internalization of epithelial tight junction proteins via a macropinocytosis-like process," The FASEB Journal, vol. 19, no. 8, pp. 923-933, 2005.

[5] J. Mankertz, M. Amasheh, S. M. Krug et al., "TNF $\alpha$ upregulates claudin-2 expression in epithelial HT-29/B6 cells 
via phosphatidylinositol-3-kinase signaling," Cell and Tissue Research, vol. 336, no. 1, pp. 67-77, 2009.

[6] R. Al-Sadi, D. M. Ye, K. Dokladny, and T. Y. Ma, "Mechanism of IL-1 $\beta$-induced increase in intestinal epithelial tight junction permeability," The Journal of Immunology, vol. 180, no. 8, pp. 5653-5661, 2008.

[7] L. W. Peterson and D. Artis, "Intestinal epithelial cells: regulators of barrier function and immune homeostasis," Nature Reviews Immunology, vol. 14, no. 3, pp. 141-153, 2014.

[8] K. Mitsuyama, M. Sata, and K. Tanikawa, "Significance of interleukin-6 in patients with inflammatory bowel disease," Gastroenterologia Japonica, vol. 26, no. 1, pp. 20-28, 1991.

[9] L. Ding, Z. Lu, O. Foreman et al., "Inflammation and disruption of the mucosal architecture in claudin-7-deficient mice," Gastroenterology, vol. 142, no. 2, pp. 305-315, 2012.

[10] T. Suzuki, N. Yoshinaga, and S. Tanabe, "Interleukin-6 (IL-6) regulates claudin-2 expression and tight junction permeability in intestinal epithelium," The Journal of Biological Chemistry, vol. 286, no. 36, pp. 31263-31271, 2011.

[11] S. Grivennikov, E. Karin, J. Terzic et al., "IL-6 and Stat3 are required for survival of intestinal epithelial cells and development of colitis-associated cancer," Cancer Cell, vol. 15, no. 2, pp. 103-113, 2009.

[12] L.-J. Huang, Q. Zhu, M. Lei, and Q. Cao, "Current use of immunosuppressive agents in inflammatory bowel disease patients in East China," World Journal of Gastroenterology, vol. 15, no. 24, pp. 3055-3059, 2009.

[13] T. H. Chung, T. J. Kang, W.-K. Cho et al., "Effectiveness of the novel herbal medicine, KIOM-MA, and its bioconversion product, KIOM-MA128, on the treatment of atopic dermatitis," Evidence-Based Complementary and Alternative Medicine, vol. 2012, Article ID 762918, 9 pages, 2012.

[14] D.-S. Kim, S.-H. Kim, B.-K. Kim, M. C. Yang, and J. Y. Ma, "Antiasthmatic effects of herbal complex MA and its fermented product MA128," Evidence-Based Complementary and Alternative Medicine, vol. 2012, Article ID 769508, 12 pages, 2012.

[15] A. Kim, M. Im, N.-H. Yim, Y.-H. Hwang, H. J. Yang, and J. Y. $\mathrm{Ma}$, "The novel herbal cocktail MA128 suppresses tumor growth and the metastatic potential of highly malignant tumor cells," Oncology Reports, vol. 34, no. 2, pp. 900-912, 2015.

[16] A. Kim and J. Y. Ma, "Anti-melanogenic activity of the novel herbal medicine, MA128, through inhibition of tyrosinase activity mediated by the p38 mitogen-activated protein kinases and protein kinase signaling pathway in B16F10 cells," Pharmacognosy Magazine, vol. 10, no. 39, pp. S463-S471, 2014.

[17] F. Ke, P. K. Yadav, and L. Z. Ju, "Herbal medicine in the treatment of ulcerative colitis," Saudi Journal of Gastroenterology, vol. 18, no. 1, pp. 3-10, 2012.

[18] F.-Y. Wang, M. Su, Y.-Q. Zheng et al., "Herbal prescription Chang'an II repairs intestinal mucosal barrier in rats with postinflammation irritable bowel syndrome," Acta Pharmacologica Sinica, vol. 36, no. 6, pp. 708-715, 2015.

[19] A.-R. Im, J. H. Y. Song, M. Y. O. Lee, S. H. U. Yeon, K. A. N. Um, and S. Chae, "Anti-wrinkle effects of fermented and non-fermented Cyclopia intermedia in hairless mice," $B M C$ complementary and alternative medicine, vol. 14, article 424, 2014.

[20] J.-W. Jung, H.-R. Kang, G.-E. Ji et al., "Therapeutic effects of fermented red ginseng in allergic rhinitis: a randomized, double-blind, placebo-controlled study," Allergy, Asthma \& Immunology Research, vol. 3, no. 2, pp. 103-110, 2011.

[21] E. M. Selhub, A. C. Logan, and A. C. Bested, "Fermented foods, microbiota, and mental health: ancient practice meets nutritional psychiatry," Journal of Physiological Anthropology, vol. 33, no. 1, article 2, 2014.

[22] H. S. Shin, S. Y. Jung, S. Y. Back, J.-R. Do, and D.-H. Shon, "Arctigenin from Fructus Arctii (seed of burdock) reinforces intestinal barrier function in Caco-2 cell monolayers," EvidenceBased Complementary and Alternative Medicine, vol. 2015, Article ID 368105, 7 pages, 2015.

[23] M. X. Chen, J. Hao, Q. Z. Yang, and G. Li, "Effects of icariin on reproductive functions in male rats," Molecules, vol. 19, no. 7, pp. 9502-9514, 2014.

[24] L. Li, H. J. Tsai, and X. M. Wang, "Icariin inhibits the increased inward calcium currents induced by amyloid-beta(25-35) Peptide in CA1 pyramidal neurons of neonatal rat hippocampal slice," American Journal of Chinese Medicine, vol. 38, no. 1, pp. 113-125, 2010.

[25] L. González-Mariscal, A. Betanzos, P. Nava, and B. E. Jaramillo, "Tight junction proteins," Progress in Biophysics and Molecular Biology, vol. 81, no. 1, pp. 1-44, 2003.

[26] C. T. Capaldo and A. Nusrat, "Cytokine regulation of tight junctions," Biochimica et Biophysica Acta-Biomembranes, vol. 1788, no. 4, pp. 864-871, 2009.

[27] Z. Pei, L. Yang, and J. R. Williamson, "Phospholipase C- $\gamma 1$ binds to actin-cytoskeleton via its C-terminal SH2 domain in vitro," Biochemical and Biophysical Research Communications, vol. 228, no. 3, pp. 802-806, 1996.

[28] J. M. Haugh, A. Wells, and D. A. Lauffenburger, "Mathematical modeling of epidermal growth factor receptor signaling through the phospholipase C pathway: mechanistic insights and predictions for molecular interventions," Biotechnology and Bioengineering, vol. 70, no. 2, pp. 225-238, 2000.

[29] Y. Wang, A. Tomar, S. P. George, and S. Khurana, “Obligatory role for phospholipase C- $\gamma 1$ in villin-induced epithelial cell migration," American Journal of Physiology-Cell Physiology, vol. 292, no. 5, pp. C1775-C1786, 2007.

[30] J. C. Song, C. M. Hanson, V. Tsai, O. C. Farokhzad, M. Lotz, and J. B. Matthews, "Regulation of epithelial transport and barrier function by distinct protein kinase C isoforms," American Journal of Physiology-Cell Physiology, vol. 281, no. 2, pp. C649C661, 2001.

[31] L. Shen, E. D. Black, E. D. Witkowski et al., "Myosin light chain phosphorylation regulates barrier function by remodeling tight junction structure," Journal of Cell Science, vol. 119, no. 10, pp. 2095-2106, 2006.

[32] K. G. E. Scott, J. B. Meddings, D. R. Kirk, S. P. LeesMiller, and A. G. Buret, "Intestinal infection with Giardia spp. reduces epithelial barrier function in a myosin light chain kinasedependent fashion," Gastroenterology, vol. 123, no. 4, pp. 11791190, 2002.

[33] T. Y. Ma, M. A. Boivin, D. Ye, A. Pedram, and H. M. Said, "Mechanism of TNF- $\alpha$ modulation of Caco-2 intestinal epithelial tight junction barrier: role of myosin light-chain kinase protein expression," American Journal of Physiology-Gastrointestinal and Liver Physiology, vol. 288, no. 3, pp. G422-G430, 2005.

[34] D. Yu, A. M. Marchiando, C. R. Weber et al., "MLCK-dependent exchange and actin binding region-dependent anchoring of 
ZO-1 regulate tight junction barrier function," Proceedings of the National Academy of Sciences of the United States of America, vol. 107, no. 18, pp. 8237-8241, 2010.

[35] A. M. Marchiando, Y. F. Guan, A. L. Hecht et al., "The tight junction proteins ZO-1 and occludin undergo novel MLCKindependent redistribution during TNF-induced cell shedding," The FASEB Journal, vol. 22, p. 1182.8, 2008. 


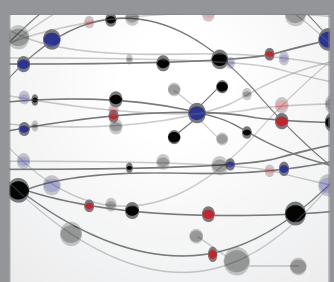

The Scientific World Journal
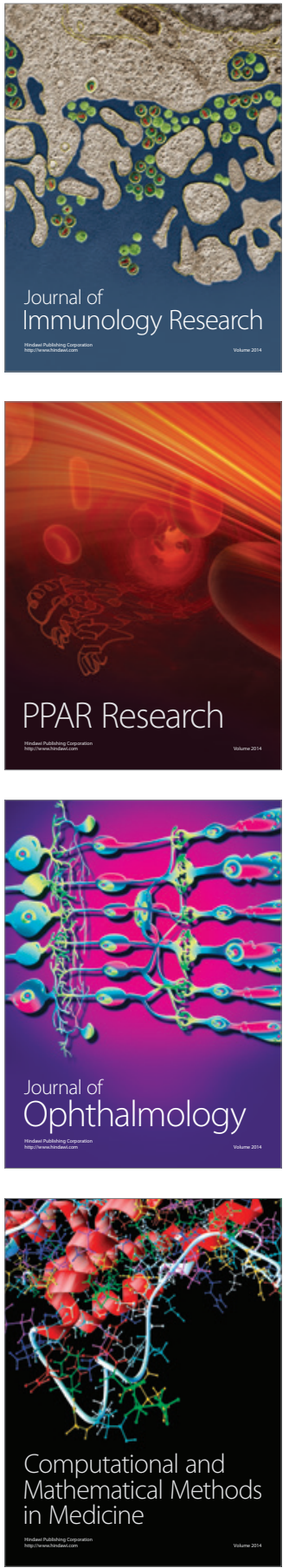

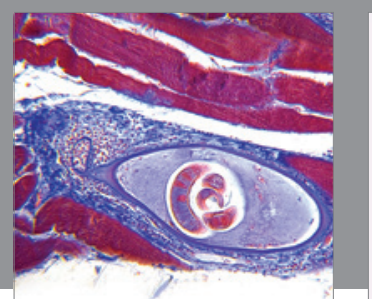

Gastroenterology Research and Practice

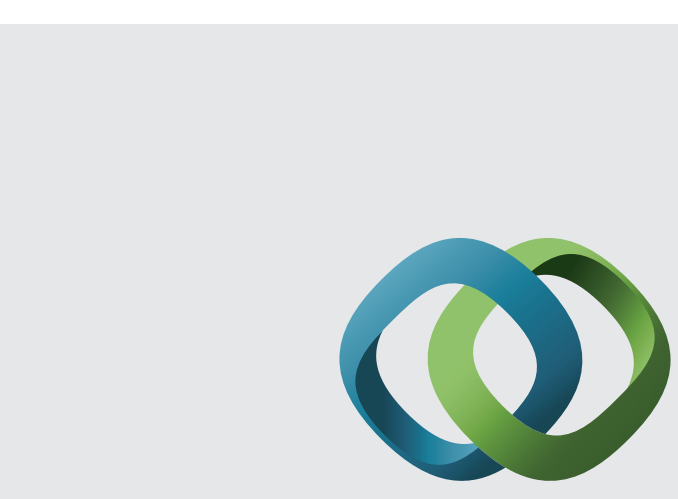

\section{Hindawi}

Submit your manuscripts at

http://www.hindawi.com
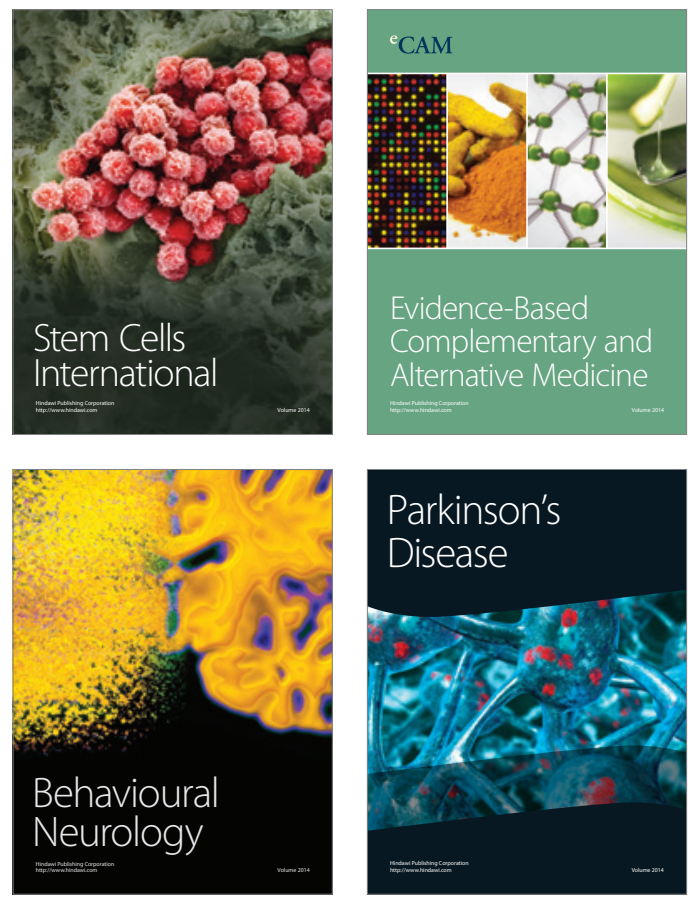
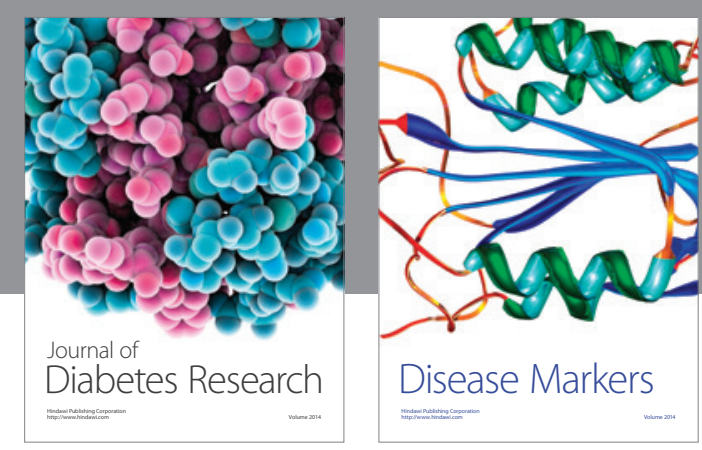

Disease Markers
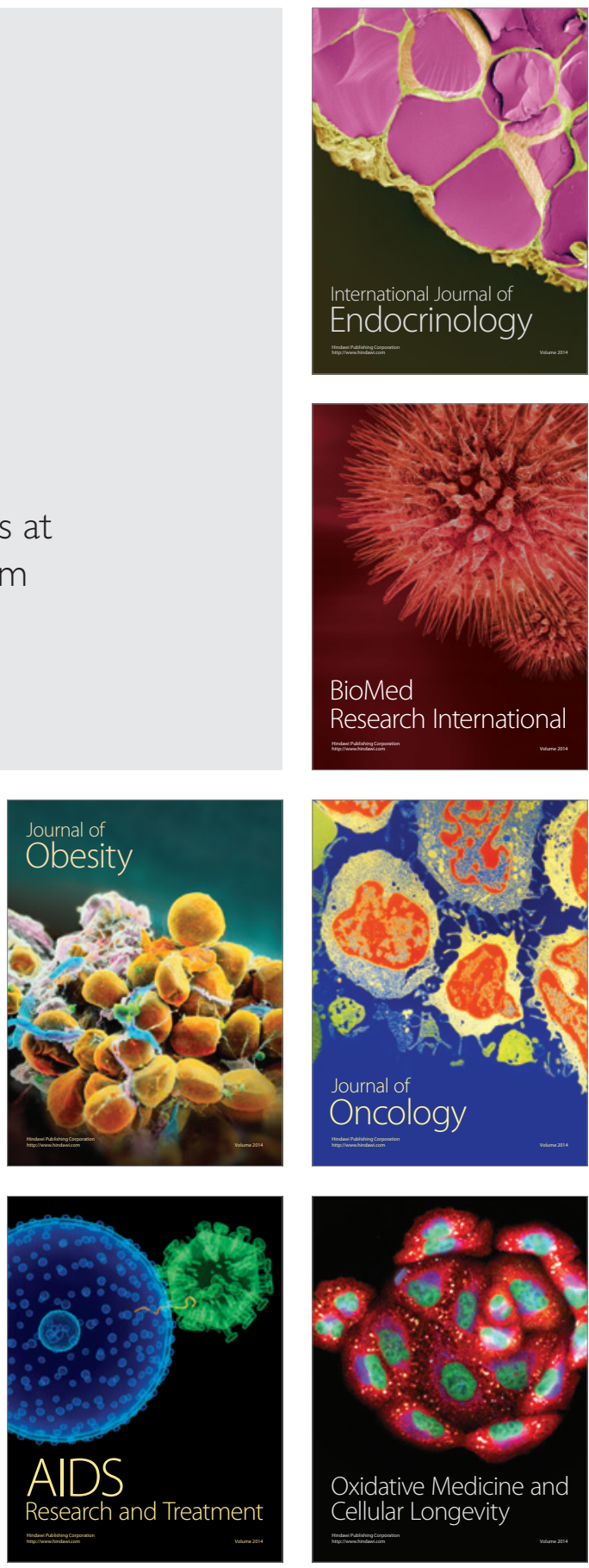